\title{
Advanced Powder Technology \\ Synthesis of Rutile TiO2 Powder by Microwave-Enhanced Roasting followed by Hydrochloric Acid Leaching \\ --Manuscript Draft--
}

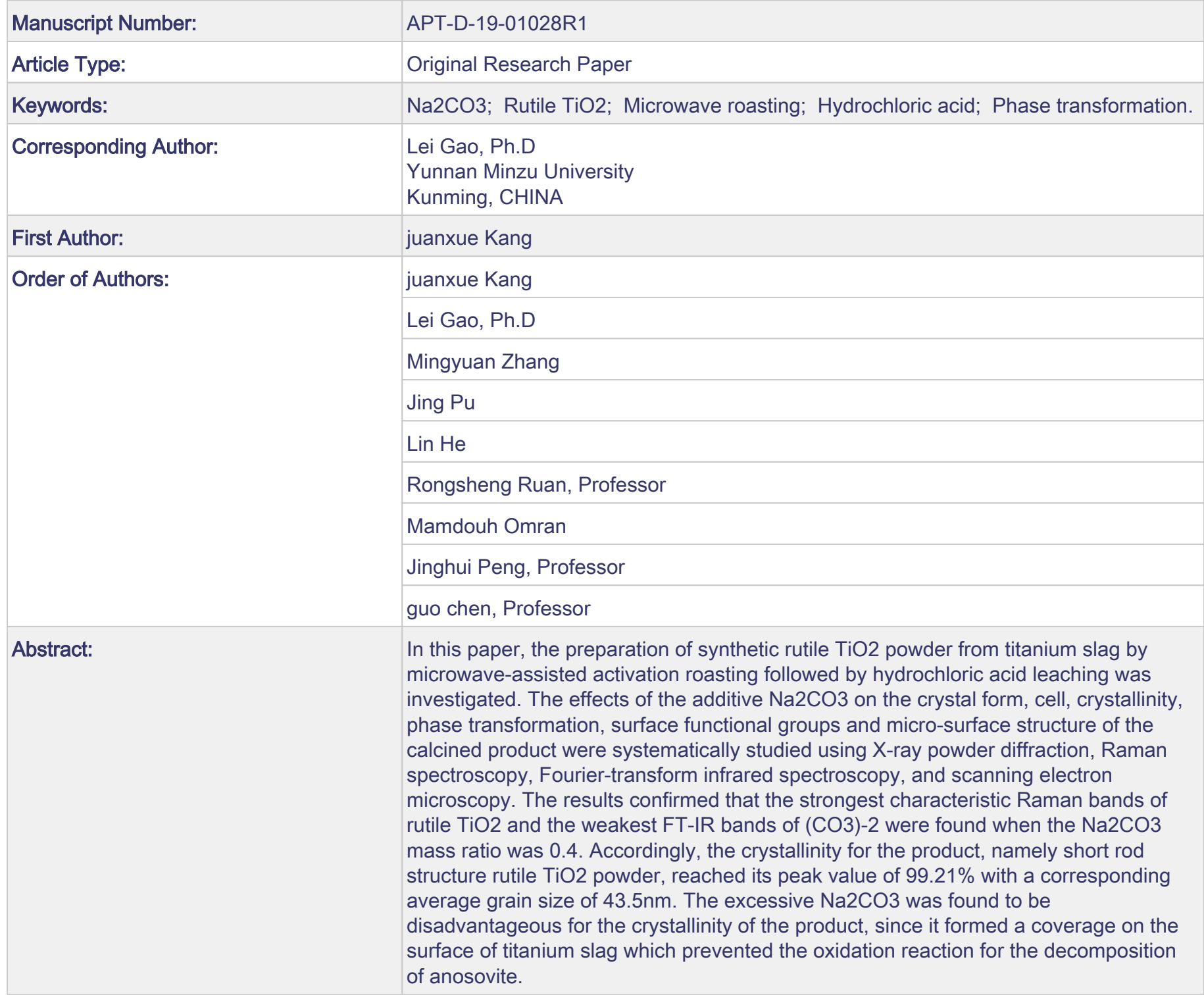


- Rutile $\mathrm{TiO}_{2}$ powder has been synthesized by optimized microwave-enhanced roasting.

- The effects of $\mathrm{Na}_{2} \mathrm{CO}_{3}$ on the formation of rutile $\mathrm{TiO}_{2}$ were characterized.

- Mechanisms of phase transformation during microwave heating were obtained. 


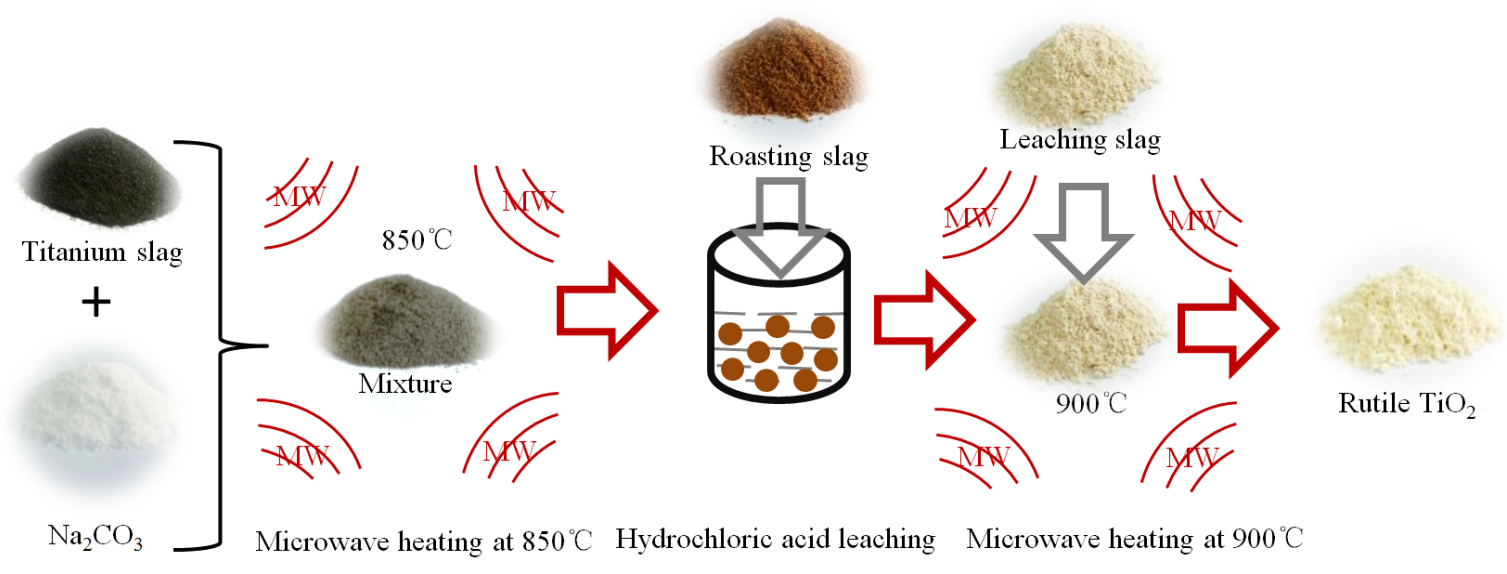




\section{Declaration of interests}

$\bigotimes$ The authors declare that they have no known competing financial interests or personal relationships that could have appeared to influence the work reported in this paper.

$\square$ The authors declare the following financial interests/personal relationships which may be considered as potential competing interests:

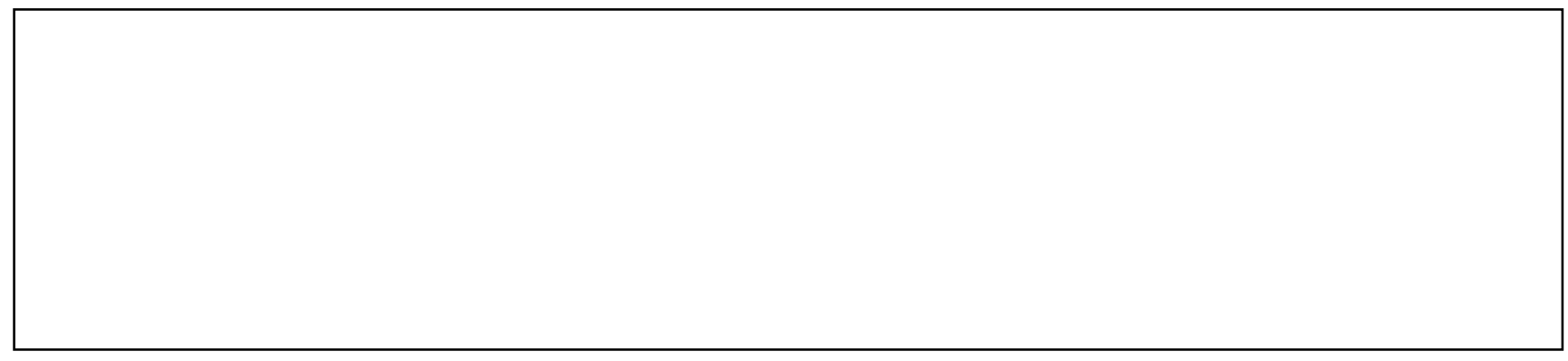




\section{Synthesis of Rutile $\mathrm{TiO}_{2}$ Powder by Microwave-Enhanced Roasting followed by \\ Hydrochloric Acid Leaching}

Juanxue Kang a , Lei Gao ${ }^{\text {a,** }}$, Mingyuan Zhang ${ }^{\text {a }, ~ J i n g ~} \mathrm{Pu}^{\text {a }}$, Lin $\mathrm{He}^{\text {a }}$, Rongsheng Ruan

a,d , Mamdouh Omran e, Jinghui Peng ${ }^{\text {a,b }}$, Guo Chen ${ }^{\text {a,b,c,* }}$

${ }^{a}$ Key Laboratory of Green-Chemistry Materials in University of Yunnan Province,

Kunming Key Laboratory of Energy Materials Chemistry, Yunnan Minzu University,

Kunming 650500, P.R. China.

${ }^{\mathrm{b}}$ Key Laboratory of Unconventional Metallurgy, Ministry of Education, Faculty of

Metallurgical and Energy Engineering, Kunming University of Science and

Technology, Kunming 650093, P.R. China.

${ }^{c}$ State Key Laboratory of Vanadium and Titanium Resources Comprehensive

Utilization, Pangang Group Research Institute Co., Ltd., Panzhihua 617000, P.R.

China.

${ }^{\mathrm{d}}$ Center for Biorefining, Bioproducts and Biosystems Engineering Department,

University of Minnesota, 1390 Eckles Ave., Saint Paul, MN 55108, USA.

${ }^{\mathrm{e}}$ Process Metallurgy Research Group, Faculty of Technology, University of Oulu, Finland. P.O. Box: 4300, Finland.

* Corresponding author: Tel: +86-871-65910017; Fax: +86-871-65910017

E-mail address: guochen@kust.edu.cn

** Co-Corresponding author: Tel: +86-871-65910017; Fax: +86-871-65910017

E-mail address: glkust2013@hotmail.com 
of anosovite.

Keywords: $\mathrm{Na}_{2} \mathrm{CO}_{3}$; Rutile $\mathrm{TiO}_{2}$; Microwave roasting; Hydrochloric acid; Phase transformation 


\section{Introduction}

Rutile $\mathrm{TiO}_{2}$ is one of the important raw materials for the production of titanium pigment and titanium sponge ${ }^{[1]}$. With the gradual depletion of natural rutile, a lowcost, environmentally friendly production technique for the rutile $\mathrm{TiO}_{2}$ is in urgent demand ${ }^{[2-5]}$. Ilmenite and titanium slags are, therefore, becoming main raw materials for rutile $\mathrm{TiO}_{2}$ in titanium industry ${ }^{[6]}$. The methods for preparation of rutile $\mathrm{TiO}_{2}$ from ilmenite or titanium slag including electrothermal reduction, molten salt roasting and acid leaching ${ }^{[7-10]}$. However, the quality of rutile $\mathrm{TiO}_{2}$ prepared by electrothermal reduction is challenged by the stubborn impurities such as $\mathrm{Fe}$ and $\mathrm{Mg}^{[7]}$. The $\mathrm{NaOH}$ or $\mathrm{KOH}$ applied in the molten salt roasting is highly corrosive $\mathrm{e}^{[11,12]}$. Thus, acid leaching, namely sulfuric acid leaching process and hydrochloric acid leaching process, are the most widely used method among the technologies reported for producing synthetic rutile $\mathrm{TiO}_{2}{ }^{[9,10]}$.

However, the application of sulfuric acid leaching process is limited by the complicated by-products including intractable waste ${ }^{[13,14]}$. Conversely, hydrochloric acid leaching process achieves more attention since it has the advantages of high leaching efficiency, strong impurity removal ability, high product grade and recycling of hydrochloric acid ${ }^{[10,15]}$. High purity synthetic rutile was successfully obtained by mechanical activated hydrochloric acid leaching and solution reduction method (adding iron powder as reducing agent in hydrochloric acid leaching process), respectively ${ }^{[16,17]}$. It was reported that rutile $\mathrm{TiO}_{2}$ with $92.65 \%$ grade of purity was synthetized by pressure leaching at $140^{\circ} \mathrm{C}$ using $20 \%$ hydrochloric acid with ilmenite 
(liquid-solid mass ratio 8:1) ${ }^{[18]}$. The purpose for the application of pressure leaching is to reduce the leaching time from 6 hours to 4 hours.

Recently, Chen et.al. introduced a novel process with five steps including hydrochloric acid leaching for the synthesis of rutile $\mathrm{TiO}_{2}$ from titanium slags, which utilized a microwave sodium salt $\left(\mathrm{Na}_{2} \mathrm{CO}_{3}\right)$ roasting to improve the leaching efficiency ${ }^{[19]}$. Microwave irradiation technology is known to be superior to the use of conventional heating on accelerating reaction rates, improving yields, and selectively activating or suppressing reaction pathways ${ }^{[20-24]}$. Microwaves are in the radio frequency portion of the electromagnetic spectrum between 0.3 to $300 \mathrm{GHz}$ with corresponding wavelengths ranging from $1 \mathrm{~m}$ to $1 \mathrm{~mm}^{[25-30]}$. Microwave energy passing through a sample, and resulting internal friction produces heat. Thus, the sample is heated from within, and heating time is greatly reduced compared with heating by external application of heat ${ }^{[31]}$. Nowadays, microwave irradiation technology is being widely used in laboratory scale as well as for commercial industrial manufacturing processes ${ }^{[32-36]}$.

The role of sodium salt during the preparation of rutile $\mathrm{TiO}_{2}$ from titanium slags was to decompose the anosovite into alkali titanate ${ }^{[37]}$. It was also noticed that the sodium salt acted as a flux during the roasting process. During the leaching process, the alkali titanate dissociates into insoluble rutile $\left(\mathrm{TiO}_{2}\right)$ in aqueous media, and separate with other soluble component ${ }^{[38]}$. Laxmi et.al. recommended an additive $\left(\mathrm{Na}_{2} \mathrm{CO}_{3}\right)$ to ilmenite ratio of $1: 1$ for the soda ash roasting of red sediment ilmenite $\left(47.03 \% \mathrm{TiO}_{2}\right)$ [39]. The molar ratio of $\mathrm{Na}_{2} \mathrm{CO}_{3} /$ titanium dioxide for the roasting of ilmenite $(42.00 \%$ 
$\mathrm{TiO}_{2}$ ) recommended by El-Tawil et.al. was $0.5^{[40]}$. Mass ratio of the additive $\mathrm{Na}_{2} \mathrm{CO}_{3}$ was proved to be a key factor for the reaction rates during the roasting process.

In this study, rutile $\mathrm{TiO}_{2}$ powder was prepared from titanium slag using a novel microwave associated method with steps as follows: microwave roasting with $\mathrm{Na}_{2} \mathrm{CO}_{3}$, hydrochloric acid leaching and microwave calcination. Compared with similar conventional roasting-leaching combining methods for the preparation of rutile $\mathrm{TiO}_{2}$, the proposed method is simpler and more effective. With the application of microwave roasting associated with an optimized mass ratio of $\mathrm{Na}_{2} \mathrm{CO}_{3}$, the leaching efficiency was largely improved without using pressure leaching. To find out the appropriate mass ratio of $\mathrm{Na}_{2} \mathrm{CO}_{3}$, the effect of the mass ratio of $\mathrm{Na}_{2} \mathrm{CO}_{3}$ on the synthesis of rutile $\mathrm{TiO}_{2}$ was analyzed by X-ray diffraction (XRD), Fourier-transform infrared (FT-IR) spectroscopic analysis, Raman spectroscopy techniques and scanning electron microscopy (SEM).

\section{Experimental}

\subsection{Materials}

The titanium slag used in the present work was received from Panzhihua (Sichuan province, China). All the other chemical reagents utilized in this study were of analytical grade and used without further purification. The main chemical composition of titanium slag were analyzed by X-ray Fluorescence (Model: EDX8100, Shimadzu, Japan). The composition of the as-received slag is presented in Table 1, revealing $75.34 \%$ of $\mathrm{TiO}_{2}, 9.72 \%$ of total $\mathrm{Fe}, 5.87 \%$ of $\mathrm{Al}_{2} \mathrm{O}_{3}, 5.23 \%$ of $\mathrm{SiO}_{2}, 1.23 \%$ of $\mathrm{MgO}, 1.81 \%$ of $\mathrm{CaO}$ and other minor elements such as $\mathrm{S}$ and $\mathrm{P}$. 


\subsection{Experimental procedures}

The flow chart of the experimental procedure is shown in Fig.1 as follow:

(1) Roasting with $\mathrm{Na}_{2} \mathrm{CO}_{3}$

In order to increase the specific surface area of the slag, the sample was first ground into powder by planetary ball mill (Model: QM-3 ${ }_{\mathrm{SP}} 4$ ) for $180 \mathrm{~min}$. Then, $100 \mathrm{~g}$ of prepared titanium slag sample was equally divided into five parts which were separately mixed with $\mathrm{Na}_{2} \mathrm{CO}_{3}$ in an agate mortar for $10 \mathrm{~min}$. The mass ratio of the $\mathrm{Na}_{2} \mathrm{CO}_{3}$ to titanium slag for the mixtures was $0.2,0.3,0.4,0.5$ and 0.6 , respectively. Subsequently, the mixtures were placed in corundum crucibles for high temperature roasting in a microwave box reactor (model: HAMiLab-M1500) at $850^{\circ} \mathrm{C}$ for $30 \mathrm{~min}$ with a microwave heating power of $1 \mathrm{~kW}$.

(2) Hydrochloric acid leaching

The roasted slag $(10 \mathrm{~g})$ was subsequently leaching at $92^{\circ} \mathrm{C} \sim 95^{\circ} \mathrm{C}$ for 4 hours using $20 \%$ hydrochloric acid (liquid-solid mass ratio 4:1) with an activated magnetic stirrer (model: DF-101s). The leaching residue was then collected after three times of washing with water.

(3) Microwave calcination

The leaching residue was placed in corundum crucibles for high temperature roasting in a microwave box reactor (model: HAMiLab-M1500) at $900^{\circ} \mathrm{C}$ for $60 \mathrm{~min}$ with a microwave heating power of $1 \mathrm{~kW}$. After natural cooling, the calcined product was taken out for analysis.

\subsection{Characterization}


The phase structures of the titanium slag and calcined product were analyzed by Xray diffractometer (Model: D8 ADVANCE A25X, Bruker, Germany). The target source used was a $\mathrm{Cu}$ target $\mathrm{K} \alpha$-ray $(\lambda=0.154056 \mathrm{~nm})$, and the tube voltage and current were $40 \mathrm{kV}$ and $25 \mathrm{~mA}$, respectively. The data sets were collected from the scans with $2 \theta$ running from $10^{\circ}$ to $100^{\circ}$. The phase changes of titanium slag and calcined product were analyzed by Raman spectroscopy (Model: inVia, Renishaw, UK). Backscattered Raman signals were acquired using a microscope, and holographic notch filters in the spectrum scattering detection region ranged from 100 $\mathrm{cm}^{-1}$ to $800 \mathrm{~cm}^{-1}$. The surface functional groups of titanium slag and calcined product were analyzed by Fourier-transform infrared spectroscopy (Model: IS10, Nicolet, USA) with a spectral region of $4000 \sim 400 \mathrm{~cm}^{-1}$. The microstructures of the titanium slag and the calcined product were analysed using a field-emission scanning electron microscope (XL30ESEM-TM, Philips, Netherlands) with a beam spot diameter of 3.0 and an acceleration voltage of $30 \mathrm{kV}$.

\section{Results and discussion}

The chemical reactions during the sodium salt roasting can be represented by the following equations:

$$
\begin{aligned}
& \mathrm{Al}_{2} \mathrm{TiO}_{5}+2 \mathrm{Na}_{2} \mathrm{CO}_{3}=\mathrm{Na}_{2} \mathrm{TiO}_{3}+2 \mathrm{NaAlO}_{2}+2 \mathrm{CO}_{2} \\
& \mathrm{FeTi}_{2} \mathrm{O}_{5}+2 \mathrm{Na}_{2} \mathrm{CO}_{3}=2 \mathrm{Na}_{2} \mathrm{TiO}_{3}+\mathrm{FeO}+2 \mathrm{CO}_{2} \\
& \mathrm{CaTi}_{2} \mathrm{O}_{5}+2 \mathrm{Na}_{2} \mathrm{CO}_{3}=2 \mathrm{Na}_{2} \mathrm{TiO}_{3}+\mathrm{CaO}+2 \mathrm{CO}_{2} \\
& \mathrm{MgTi}_{2} \mathrm{O}_{3}+2 \mathrm{Na}_{2} \mathrm{CO}_{3}=2 \mathrm{Na}_{2} \mathrm{TiO}_{3}+\mathrm{MgO}+2 \mathrm{CO}_{2} \\
& \mathrm{SiO}_{2}+\mathrm{Na}_{2} \mathrm{CO}_{3}=\mathrm{Na}_{2} \mathrm{SiO}_{3}+\mathrm{CO}_{2}
\end{aligned}
$$


The relation between the standard Gibbs free energy and temperature for the above reactions is shown in Fig. 2(a). Apparently, the standard Gibbs free energy for the Eq.(1)-(6) are all negative at a sodium salt roasting temperature $850^{\circ} \mathrm{C}$. $\mathrm{The} \mathrm{Al}_{2} \mathrm{TiO}_{5}$, $\mathrm{FeTi}_{2} \mathrm{O}_{5}, \mathrm{CaTi}_{2} \mathrm{O}_{5}, \mathrm{MgTi}_{2} \mathrm{O}_{3}, \mathrm{SiO}_{2}$ and $\mathrm{TiO}_{2}$ will be transformed to $\mathrm{NaAlO}_{2}, \mathrm{FeO}, \mathrm{CaO}$, $\mathrm{MgO}, \mathrm{Na}_{2} \mathrm{SiO}_{3}$ and $\mathrm{Na}_{2} \mathrm{TiO}_{3}$ which will react with hydrochloric acid in the leaching procedure. The possible subsequent reactions during the leaching procedure are listed in Eq. (7)-(12), and the effects of the leaching temperature on the $\Delta G^{\theta}$ of the reactions are shown in Fig. 2(b). The results indicate that with hydrochloric acid leaching at $95^{\circ} \mathrm{C}$, the impurity elements $\mathrm{Fe}, \mathrm{Al}, \mathrm{Mg}, \mathrm{Ca}, \mathrm{Si}$ dissolve in the lixivium, whilst insoluble $\mathrm{TiO}_{2}$ forms in the leaching residue.

$\mathrm{NaAlO}_{2}+4 \mathrm{HCl}=\mathrm{NaCl}+\mathrm{AlCl}_{3}+2 \mathrm{H}_{2} \mathrm{O}$

$\mathrm{FeO}+2 \mathrm{HCl}=\mathrm{FeCl}_{2}+\mathrm{H}_{2} \mathrm{O}$

$\mathrm{CaO}+2 \mathrm{HCl}=\mathrm{CaCl}_{2}+\mathrm{H}_{2} \mathrm{O}$

$\mathrm{MgO}+2 \mathrm{HCl}=\mathrm{MgCl}_{2}+\mathrm{H}_{2} \mathrm{O}$

$\mathrm{Na}_{2} \mathrm{SiO}_{3}+2 \mathrm{HCl}=2 \mathrm{NaCl}+\mathrm{H}_{2} \mathrm{SiO}_{3}$

$\mathrm{Na}_{2} \mathrm{TiO}_{3}+2 \mathrm{HCl}=2 \mathrm{NaCl}+\mathrm{TiO}_{2}+\mathrm{H}_{2} \mathrm{O}$

\subsection{Characterization by XRD}

The crystal structure of the titanium slag was characterized by XRD and the results are illustrated in Fig. 3. The XRD pattern of titanium slag matches both the Braggposition and intensity of Iron titanium oxide (JCPDS card No. 43-1011), indicating that the main crystalline phase of the sample was $\mathrm{Fe}_{3} \mathrm{Ti}_{3} \mathrm{O}_{10}{ }^{[41,42]}$. Meanwhile, peaks 
for rutile $\mathrm{TiO}_{2}$ and anatase $\mathrm{TiO}_{2}$ were also found. The titanium slag had the strongest preferential orientation of (220) plane at $2 \theta=25.487^{\circ}$, the second and third strong preferential orientation of (230) and (020) planes of titanium slag were observed at $2 \theta=32.448^{\circ}$ and $2 \theta=18.107^{\circ}$, respectively.

The crystal structures of calcined product prepared with the additive $\left(\mathrm{Na}_{2} \mathrm{CO}_{3}\right)$ mass ratios of $0.2,0.3,0.4,0.5$ and 0.6 was characterized by XRD and the results are illustrated in Fig. 4. The XRD patterns of the calcined products match both the Braggposition and intensity of rutile $\mathrm{TiO}_{2}\left(\mathrm{JCPDS}\right.$ card No. 21-1276) ${ }^{[42,43]}$. The calcined products had the strongest preferential orientation of (110) plane at $2 \theta=27.446^{\circ}$, the second and third strong preferential orientation of (211) and (101) planes of calcined products were observed at $2 \theta=54.322^{\circ}$ and $2 \theta=36.085^{\circ}$, respectively. The results indicating that rutile $\mathrm{TiO}_{2}$ was successfully prepared with the designed experimental process. Since the leaching time was 4 hours without the requirement of pressure environment, the proposed method is simpler and more effective compared with similar conventional roasting-leaching combining methods (usually including 6 hours of leaching).That is because microwave heating is superior to the use of conventional heating on accelerating reaction rates and selectively activating.

The XRD patterns were further analyzed by Jade 5.0 software, indicating that the space point group of the calcined slag was $\mathrm{P} 4_{2} / \mathrm{mnm}(136)$, which belongs to Rutile $\mathrm{TiO}_{2}$.

The average crystallite sizes of the calcined products were estimated by applying 
Scherer's equation ${ }^{[44-46]}$ :

$\mathrm{D}=\frac{\mathrm{K} \lambda}{\beta \cos \theta}$

where D is average crystallite size in angstroms $(\AA)$ and $\mathrm{K}$ is the shape factor taken as $0.9, \lambda$ is the wavelength of $\mathrm{X}$-ray radiation $(\mathrm{Cu} \mathrm{K} \alpha=1.54056 \AA), \beta$ is the full width at half maximum (FWHM) after making appropriate base line correction and $\theta$ is the diffraction angle. The results are shown in Table 2. The average grain size of the calcined products with additive mass ratio of $0.2,0.3,0.4,0.5$ and 0.6 were $40.1 \mathrm{~nm}$, 58.0nm, 43.5nm, 44.7nm and 43.8nm, respectively. The peak appeared when the additive mass ratio was 0.3 . The corresponding crystallinity were $96.39 \%, 92.53 \%$, $99.21 \%, 98.23 \%$ and $98.45 \%$, respectively. Clearly, an excess of $\mathrm{Na}_{2} \mathrm{CO}_{3}$ was disadvantageous for the crystallinity of rutile $\mathrm{TiO}_{2}$, because it may prevent the oxidation reaction for the decomposition of anosovite ${ }^{[47]}$.

\subsection{Characterization by Raman spectroscopy}

In order to investigate the phase transformations during the experimental procedure, the as-received titanium slag and calcined products were characterized by Raman spectroscopy. Fig. 5 shows the Raman spectra of titanium slag. The Raman bands identified at frequencies of $141.8 \mathrm{~cm}^{-1}$ are attributed to the $\mathrm{E}_{\mathrm{g}}{ }^{1}$ vibrations of anatase phase ${ }^{[48,49]}$. The Raman bands identified at frequencies of $239.8 \mathrm{~cm}^{-1}$, which were caused by multiple-phonons scattering, are frequently considered as a characteristic peak of rutile phase ${ }^{[50]}$. The Raman bands identified at frequencies of $444.2 \mathrm{~cm}^{-1}$ and $609.8 \mathrm{~cm}^{-1}$ are attributed to the vibrations of rutile phase for $\mathrm{E}_{\mathrm{g}}{ }^{1}$ and $\mathrm{A}_{\mathrm{g}}{ }^{1}$, respectively. 
Fig. 6 shows the Raman spectra of calcined products with additive mass ratio of 0.2 , 0.3, 0.4, 0.5 and 0.6, respectively. The Raman bands identified at frequencies of 141.8 $\mathrm{cm}^{-1}, 444.2 \mathrm{~cm}^{-1}$ and $609.8 \mathrm{~cm}^{-1}$ are attributed to the vibrations of rutile phase for $\mathrm{B}_{\mathrm{g}}{ }^{1}$, $\mathrm{E}_{\mathrm{g}}{ }^{1}$ and $\mathrm{A}_{\mathrm{g}}{ }^{1}$. The Raman bands identified at frequencies of $236.4 \mathrm{~cm}^{-1}$ are frequently considered as a characteristic peak of rutile phase. It is worth mentioning that anatase phases has characteristic Raman peaks at $397 \mathrm{~cm}^{-1}, 515 \mathrm{~cm}^{-1}$ and $640 \mathrm{~cm}^{-1[51,52]}$, which were completely absent in the Raman spectra in Fig. 6. Clearly, anatase phases has transformed to rutile phases with the designed experimental procedure. However, the Raman bands attributed to the vibrations of rutile phase were suppressed in the Raman spectra of calcined products with excessive additive. With an additive mass ratio of 0.5 and 0.6 in Fig. 6, the Raman bands identified at frequencies of $236.4 \mathrm{~cm}^{-1}$ is suppressed and finally disappears. These results indicating that phase transformation of the rutile phase was most successful when the mass ratio of $\mathrm{Na}_{2} \mathrm{CO}_{3}$ was 0.4 , and was suppressed when an excessive of $\mathrm{Na}_{2} \mathrm{CO}_{3}$ was provided.

\subsection{Characterization by FI-IR}

The FT-IR spectra of titanium slag are shown in Fig.7. The bands at $3409.16 \mathrm{~cm}^{-1}$ which are attributed to the stretching vibrations of hydroxyl groups $(\mathrm{OH})^{[53]}$. The bands at $1644.08 \mathrm{~cm}^{-1}$ are attributed to the twisting of $\mathrm{H}-\mathrm{O}-\mathrm{H}^{[54]}$. The bands at 2362.47 $\mathrm{cm}^{-1}$ are attributed to the $\left(\mathrm{CO}_{3}\right)^{-2}$ asymmetrical and symmetrical stretching mode vibrations $^{[55]}$. The bands at $1072.51 \mathrm{~cm}^{-1}$ are attributed to the symmetrical stretching of Si-O-Si bond ${ }^{[56]}$. The bands at $546.64 \mathrm{~cm}^{-1}$ are attributed to the vibrations of the octahedral ligand of titanium dioxide. According to the Raman spectra of the titanium slag, the bands at $546.64 \mathrm{~cm}^{-1}$ was caused by octahedral ligands of anatase $\mathrm{TiO}_{2}$. 
The FT-IR spectra of the calcined product prepared with the additive $\left(\mathrm{Na}_{2} \mathrm{CO}_{3}\right)$ mass ratios of 0.2, 0.3, 0.4, 0.5 and 0.6 are shown in Fig. 8(a-e), respectively. The infrared spectroscopic vibrations with surface functional groups appear at $3417.71 \mathrm{~cm}^{-1}$, $2361.50 \mathrm{~cm}^{-1}, 1637.33 \mathrm{~cm}^{-1}$ and $1102.17 \mathrm{~cm}^{-1}$, respectively. Compared with Fig. 7, the characteristic peak at $546.64 \mathrm{~cm}^{-1}$ disappears in Fig. 8(a-b), whilst a red shift is observed since a new surface functional group infrared spectroscopic vibration appears at $544.81 \mathrm{~cm}^{-1}$ in Fig.8(c-e). Additionally, the peak strength at $2361.50 \mathrm{~cm}^{-1}$ attributed to the vibration of $\left(\mathrm{CO}_{3}\right)^{-2}$ bond firstly decreases and then increases with increasing mass ratio of additive in Fig. 8. The weakest peak value of $\left(\mathrm{CO}_{3}\right)^{-2}$ bond appears in Fig. 8(c), indicating a high efficiency for $\mathrm{Na}_{2} \mathrm{CO}_{3}$ modification reaction with the mass ratio of the additive equals to 0.4 . Unreacted $\mathrm{Na}_{2} \mathrm{CO}_{3}$ appeared in the final products with an additive $\mathrm{Na}_{2} \mathrm{CO}_{3}$ mass ratio of 0.5 or higher.

\subsection{Characterization by SEM}

Scanning electron microscopy (SEM) was employed to investigate the change of morphology of titanium slag. The results is shown in Fig. 9(a), indicating a denser and smoother surface morphology of the sample. The microstructure for the calcined product prepared with the additive $\left(\mathrm{Na}_{2} \mathrm{CO}_{3}\right)$ mass ratios of $0.2,0.3,0.4,0.5$ and 0.6 are presented in Fig.9 (b-f). With the increasing mass ratio of $\mathrm{Na}_{2} \mathrm{CO}_{3}$, the microstructure of the calcined product gradually transforms into a rode-like shape in Fig. 9(b-c). However, because of an excess of the additive, the short rod structure continues transforming towards a flat compact structure, as shown in Fig. 9(d-f).

\section{Conclusion}


In this paper, the synthesis of rutile $\mathrm{TiO}_{2}$ powder from titanium slag by microwaveassisted activation roasting followed by hydrochloric acid leaching was investigated. The main findings of the study are summarized as follows:

(1) The results of XRD, Raman spectra and FT-IR spectra indicating that rutile $\mathrm{TiO}_{2}$ powder was successfully prepared with the designed experimental process. Since the microwave heating is superior to the use of conventional heating on accelerating reaction rates and selectively activating, the proposed method is simpler and more effective compared with similar conventional roasting-leaching combining methods. (2) The effects of the additive $\mathrm{Na}_{2} \mathrm{CO}_{3}$ on the calcined product were systematically studied, and the optimized additive mass ratio was 0.4 . With this optimized $\mathrm{Na}_{2} \mathrm{CO}_{3}$ mass ratio, the crystallinity for the rutile $\mathrm{TiO}_{2}$ product reached its peak value which was $99.21 \%$, and the corresponding average grain size was $43.5 \mathrm{~nm}$.

(3) Unreacted $\mathrm{Na}_{2} \mathrm{CO}_{3}$ appeared in the final products with an additive $\mathrm{Na}_{2} \mathrm{CO}_{3}$ mass ratio of 0.5 or higher. The excessive $\mathrm{Na}_{2} \mathrm{CO}_{3}$ was found to be disadvantageous for the crystallinity of the product, since it formed a coverage on the surface of titanium slag which prevented the oxidation reaction for the decomposition of anosovite.

(4) For the microstructure evolution tendency, the dense and smooth surface morphology of the titanium slag was successfully decomposed with the designed experimental process. Short rod structure rutile $\mathrm{TiO}_{2}$ powder were found in the calcined product with appropriate additive mass ratio.

\section{Acknowledgments}


The authors acknowledge the financial support from the National Natural Science

Foundation of China (No: U1802255, 51504110 and 51424114), Yunnan Applied

Basic Research Project of China (No: 2017FD117) and Innovative Research Team (in Science and Technology) in University of Yunnan Province were sincerely acknowledged.

\section{References}

[1] J. Song, J. Qin, J. Qu, Z. Song, W. Zhang, X. Xue, Y. Shi, T. Zhang, W. Ji, R. Zhang, H. Zhang, Z. Zhang, X. Wu, The effects of particle size distribution on the optical properties of titanium dioxide rutile pigments and their applications in cool non-white coatings, Solar Energy Materials and Solar Cells, 130 (2014) $42-50$.

[2] D. Yang, F. Gao, B. Sun, X. Gong, Materials flow analysis of metallic titanium in China, Materials Science Forum, 898 (2017) 2446-2454.

[3] Z. Yuan, Y. Pan, E. Zhou, X. Cong, S. Li, Comprehensive utilization of complex titania ore, Journal of Iron and Steel Research International, 14 (2007) $0-6$.

[4] G. Chen, K. Xiong, J. Peng, J. Chen, Optimization of combined mechanical activation-roasting parameters of titania slag using response surface methodology, Advanced Powder Technology, 21 (2010) 331-335.

[5] G. Chen, J. Chen, C. Srinivasakannan, J. Peng, Application of response surface methodology for optimization of the synthesis of synthetic rutile from titania slag, Applied Surface Science, 258 (2012) 3068-3073. 
[6] Y. Guo, S. Liu, T. Jiang, G. Qiu, Study on preparation of high-quality synthetic rutile from titanium slag by activation roasting followed by acid leaching, 2nd International Symposium on High-Temperature Metallurgical Processing, (2011) 125-135.

[7] J. J. Ru, Y. X. Hua, C. Y. Xu, Q. B. Zhang, D. Wang, K. Gong, Synthesis of TiN from $\mathrm{FeTiO}_{3}$ by microwave-assisted carbothermic reduction-nitridation, Journal of Alloys and Compounds, (583) 2014 121-127.

[8] D. Wang, J. L. Chu, Y. Liu, J. Li. Novel process for titanium dioxide production from titanium slag: $\mathrm{NaOH}-\mathrm{KOH}$ binary molten salt roasting and water leaching, Industrial \& Engineering Chemistry Research, 52 (45) 2013 $15756-15762$.

[9] X. H. Xiong, Z. X. Wang, F. X. Wu, X. H. Li, H. J. Guo, Preparation of $\mathrm{TiO}_{2}$ from ilmenite using sulfuric acid decomposition of the titania residue combined with separation of $\mathrm{Fe}^{3+}$ with EDTA during hydrolysis, Advanced Powder Technology, (24) 2013 60-67.

[10] L. S. Zhao, Y. H. Liu, L. N. Wang, H. X. Zhao, D. S. Chen, B. N. Zhong, J. C. Wang, T. Qi, Production of rutile $\mathrm{TiO}_{2}$ pigment from titanium slag obtained by hydrochloric acid leaching of vanadium-bearing titanomagnetite, Industrial \& Engineering Chemistry Research, (53) 2014 70-77.

[11] Y. Feng, J. G. Wang, L. N. Wang, T. Qi, T. Y. Xue, J. L. Chu, Decomposition of acid dissolved titanium slag from Australia by sodium hydroxide, Rare Metals, 28(6) 2009 564-569.

[12] Y. H. Liu, F. C. Meng, F. Q. Fang, W. J. Wang, J. L. Chu, T. Qi, Preparation of rutile titanium dioxide pigment from low-grade titanium slag pretreated by the $\mathrm{NaOH}$ molten salt method, Dyes and Pigments, (125) 2016 384-391.

[13] C. Li, B. Liang, H. Song, J. Xu, X. Wang, Preparation of porous rutile titania from ilmenite by mechanical activation and subsequent sulfuric acid leaching, 
Microporous \& Mesoporous Materials, 115 (2008) 293-300.

[14] Z. Li, Z. Wang, G. Li, Preparation of nano-titanium dioxide from ilmenite using sulfuric acid-decomposition by liquid phase method, Powder Technology, 287 (2016) 256-263.

[15] T. Ogasawara, R. Araújo. Hydrochloric acid leaching of a pre-reduced Brazilian ilmenite concentrate in an autoclave, Hydrometallurgy, 56 (2000) 203-216.

[16] C. Li, B. Liang, H. Wang, Preparation of synthetic rutile by hydrochloric acid leaching of mechanically activated Panzhihua ilmenite, Hydrometallurgy, 91 (2008) 121-129.

[17] M.H.H. Mahmoud, A.A.I. Afifi, I.A. Ibrahim, Reductive leaching of ilmenite ore in hydrochloric acid for preparation of synthetic rutile, Hydrometallurgy, 73 (2004) 99-109.

[18] J. Xiang, S. Liu, X. Lv, C. Bai., Preparation of rutile from ilmenite concentrate through pressure leaching with hydrochloric acid, Metallurgical \& Materials Transactions B, 48 (2017) 1333-1341.

[19] G. Chen, J. Pu, J. Chen, J. Peng, C. Srinivasakannan, R. Ruan, Multi-scale investigation of the formation and properties of high-grade rutile $\mathrm{TiO}_{2}$, from titanium slags using microwave heating, Royal Society Open Science, 5 (2018) 171858.

[20] K. Q. Li, J. Chen, G. Chen, J. H. Peng, R. Ruan, C. Srinivasakannan, Microwave dielectric properties and thermochemical characteristics of the 
mixtures of walnut shell and manganese ore, Bioresource Technology, 286 (2019) 121381.

[21] K. Q. Li, G. Chen, J. Chen, J. H. Peng, R. Ruan, C. Srinivasakannan, Microwave pyrolysis of walnut shell for reduction process of low-grade pyrolusite, Bioresource Technology, 291 (2019) 121838.

[22] K. Q. Li, G. Chen, X. T. Li, J. H. Peng, R. Ruan, M. Omran, J. Chen, Hightemperature dielectric properties and pyrolysis reduction characteristics of different biomass-pyrolusite mixtures in microwave field, Bioresource Technology, 294 (2019) 122217.

[23] K. Q. Li, J. Chen, J. H. Peng, R. Ruan, M. Orman, G. Chen, Dielectric properties and thermal behavior of electrolytic manganese anode mud in microwave field, Journal of Hazardous Materials, 13 (2019) 121227

[24] M. Y. Zhang, L. Gao, J. X. Kang, J. Pu, J. H. Peng, M. Omran, G. Chen, Stability optimisation of CaO-doped partially stabilised zirconia by microwave sintering, Ceramics International, 45 (2019) 23278-23282.

[25] A. Mudhoo, S. K. Sharma, Microwave irradiation technology in waste sludge and wastewater treatment research, Critical Reviews in Environmental Science and Technology, 41 (2011) 999-1066.

[26] M. Omran, T. Fabritius, A. M. Elmahdy, N. A. Abdel-Khalek, M. El-Aref, A. E. Elmanawi, Effect of microwave pre-treatment on the magnetic properties of iron ore and its implications on magnetic separation, Separation \& Purification Technology, 136 (2014) 223-232. 
[27] J. Vereš, M. Lovás, Š. Jakabský, V. Šepelák, S. Hredzák, Characterization of blast furnace sludge and removal of zinc by microwave assisted extraction, Hydrometallurgy, 129-130 (2012) 67-73.

[28] M. Omran, T. Fabritius, A. M. Elmahdy, N. A. Abdel-Khalek, S. Gornostayev, Improvement of phosphorus removal from iron ore using combined microwave pretreatment and ultrasonic treatment, Separation \& Purification Technology, 156 (2015) 724-737.

[29] M. Omran, T. Fabritius, R. Mattila, Thermally assisted liberation of high phosphorus oolitic iron ore: a comparison between microwave and conventional furnaces, Powder Technology, 269 (2015) 7-14.

[30] C. Liu, L. Zhang, J. Peng, C. Srinivasakannan, B. Liu, H. Xia, J. Zhou, L. Xu, Temperature and moisture dependence of the dielectric properties of silica sand, Journal of Microwave Power \& Electromagnetic Energy, 47 (3) (2016) 199-209.

[31] M. Al-Harahsheh, S. Kingman, S. Bradshaw, The reality of non-thermal effects in microwave assisted leaching systems, Hydrometallurgy, 84 (1-2) (2006) 1-13.

[32] G. Chen, J. Chen, X. Zhi, C. Srinivasakannan, J. Peng, Synthesis and microwave absorption characteristics of corundum-mullite refractories, Refractories \& Industrial Ceramics, 55 (3) (2014) 231-235. G. Chen, J. Chen, Z. Zhang, S. Guo, Z. Zhang, J. Peng, C. Srinivasakannan, X. Li, Y. Zhuang, Z. Xu, Leaching of refractory gold ores by microwave 
irradiation: comparison with conventional leaching, Metallurgist, 57 (2013) $647-653$.

[34] B. Chen, D. Chen, Z. Kang, Y. Zhang, Preparation and microwave absorption properties of Ni-Co nanoferrites, J. Alloys Compd., 618 (2015) 222-226.

[35] D. Chen, D. Li, Z. Kang, Preparation of magnesiumferrite nanoparticles by ultrasonic wave-assisted aqueous solution ball milling, Ultrasonics Sonochemistry, 20 (6) (2013) 1337-1340.

[36] D. Chen, X. Yi, Z. Chen, Y. Zhang, B. Chen, Z. Kang, Synthesis of $\mathrm{CoFe}_{2} \mathrm{O}_{4}$ nanoparticles by a low temperature microwave-assisted ball-milling technique, Int. J. Appl. Ceram. Technol., 11 (5) (2014) 954-959.

[37] S. Segado, A. Lahiri, A. Jha, Alkali roasting of bomar ilmenite: rare earths recovery and physico-chemical changes, Open Chemistry, 13 (2014) 270-278.

[38] A. Lahiri, A. Jha, Kinetics and reaction mechanism of soda ash roasting of ilmenite ore for the extraction of titanium dioxide, Metallurgical and Materials Transactions B, 38 (6) 939-948.

[39] T. Laxmi, R. Mohapatra, R. B. Rao, Preliminary investigations on alkali leaching kinetics of red sediment ilmenite slag, Korean J. Chem. Eng., 30 (1) (2013) 123-130.

[40] S. Z. El-Tawil , I. M. Morsi, A. Yehia, A. A. Francis, Alkali reductive roasting of ilmenite ore, Canadian Metallurgical Quarterly, 35 (1996) 31-37.

[41] G. Chen, J. Chen, Z. Song, C. Srinivasakannan, J. Peng, A new highly efficient method for the synthesis of rutile $\mathrm{TiO}_{2}$, Journal of Alloys and Compounds, 585 
(2014) 75-77.

[42]

H. Chen, G. Chen, Y. Wu, J. Peng, C. Srinivasakannan, J. Chen, Synthesis of rutile $\mathrm{TiO}_{2}$ from Panzhihua sulfate titanium slag by microwave heating, JOM, 68 (12) (2017) 2600-2665.

[43] A. He, G. Chen, J. Chen, J. Peng, C. Srinivasakannan, R. Ruan, A novel method of synthesis and investigation on transformation of synthetic rutile powders from Panzhihua sulphate titanium slag using microwave heating, Powder Technology, 323 (2018) 115-119.

[44] M. C. Mathpal, A. K. Tripathi, M. K. Singh, S. P. Gairolad, S. P. Gairolad, A. Agarwala, Effect of annealing temperature on Raman spectra of $\mathrm{TiO}_{2}$ nanoparticles, Chemical Physics Letters, 555 (Complete) (2013) 182-186.

[45] A. K. Tripathi, M. K. Singh, M. C. Mathpal, S. K. Mishrad, A. Agarwala, Study of structural transformation in $\mathrm{TiO}_{2}$ nanoparticles and its optical properties, Journal of Alloys and Compounds, 549 (none) (2013) 114-120.

[46] A. H. Mayabadi, V. S. Waman, M. M. Kamble, S. S. Ghosh, B. B. Gabhale, S. R. Rondiya, A. V. Rokade, S. S. Khadtare, V. G. Sathe, H. M. Pathan, S. W. Gosavi, S. R. Jadkar, Evolution of structural and optical properties of rutile $\mathrm{TiO}_{2}$ thin films synthesized at room temperature by chemical bath deposition method, Journal of Physics and Chemistry of Solids, 75 (2) (2014) 182-187.

[47] T. A. Lasheen, Soda ash roasting of titania slag product from Rosetta ilmenite, Hydrometallurgy, 93 (2008) 124-128.

[48] A. L. R. Rangel, J. A. M. Chaves, A. L. A. Escada, R. Konatu, K. C. Popat, A. P. R. A. Claro, Modification of the Ti15Mo alloy surface through TiO2 
nanotube growth-an in vitro study, Journal of Applied Biomaterials and Fundamental Materials, 16 (4) (2018) 1-8. H. L. Ma, J. Y. Yang, Y. Dai, Y. B. Zhang, B. Lu, G. H. Ma, Raman study of phase transformation of $\mathrm{TiO} 2$ rutile single crystal irradiated by infrared femtosecond laser, Applied Surface Science, 253 (18) (2007) 7497-7500.

[50] W. Wang, B. Gu, L. Liang, W. A. Hamilton, D. J. Wesolowski, Synthesis of rutile $\left(\alpha-\mathrm{TiO}_{2}\right)$ nanocrystals with controlled size and shape by low-temperature hydrolysis: effects of solvent composition, The Journal of Physical Chemistry B, 108 (39) (2004) 14789-14792.

[51] W. F. Zhang, Y. L. He, M. S. Zhang, Z. Yin, Q. Chen, Raman scattering study on anatase TiO2 nanocrystals, Journal of Physics D Applied Physics, 33 (8) (2000) 912-916.

[52] S. S. Amin, A. W. Nicholls, T. T. Xu, A facile approach to synthesize singlecrystalline rutile $\mathrm{TiO} 2$ one-dimensional nanostructures, Nanotechnology, 18 (44) (2007) 1-5.

[53] S. Beddiaf, S Chihi, Y Leghrieb, The determination of some crystallographic parameters of quartz, in the sand dunes of Ouargla, Algeria, Journal of African Earth Sciences, 106 (2015) 129-133.

[54] S. A. Boussaa, A. Kheloufi, N. B. Zaourar, K. Fouad, Valorization of algerian sand for photovoltaic application, Acta Physica Polonica Series a, 130 (1) (2016) 133-137.

[55] S. Gnanasaravanan, P. Rajkumar, Characterization of minerals in natural and 
manufactured sand in Cauvery River belt, Tamilnadu, India, Infrared Physics \& Technology, 58 (2013) 21-31. spectroscopic estimation of crystallinity in $\mathrm{SiO}_{2}$ based rocks, Bulletin of Materials Science, 31 (5) (2008) 775-779.

\section{Table Captions}

Table 1 Main chemical composition of the titanium slag

Table 2 Structural parameters of calcined slag

\section{Figure Captions}

Fig.1 Brief flow chart of the experimental process

Fig.2 The relation between $\Delta \mathrm{G}^{\theta}$ and temperature(T): (a) roasting process, (b) leaching process.

Fig.3 XRD pattern of titanium slag.

Fig.4 XRD patterns of calcined products with additive mass ratio of $0.2,0.3,0.4,0.5$, and 0.6.

Fig.5 Raman spectra of titanium slag.

Fig.6 Raman spectra of calcined products with additive mass ratio of 0.2, 0.3, 0.4, 0.5, and 0.6.

Fig.7 FT-IR spectra of titanium slag.

Fig.8 FT-IR spectra of calcined products with additive mass ratio of (a) 0.2 , (b) 0.3 , (c) 0.4 , (d) 0.5 , (e) 0.6. 


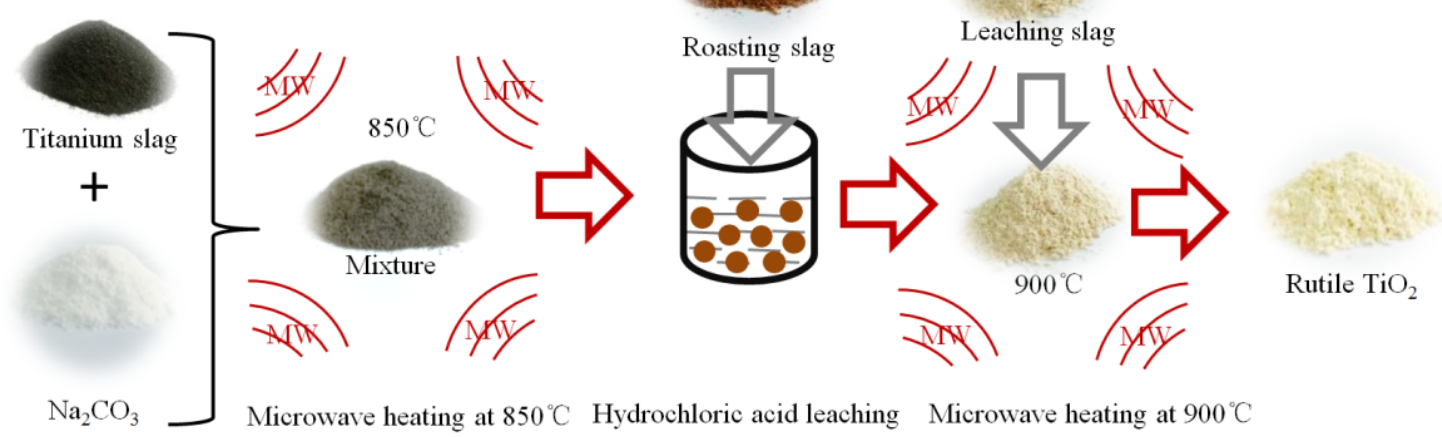




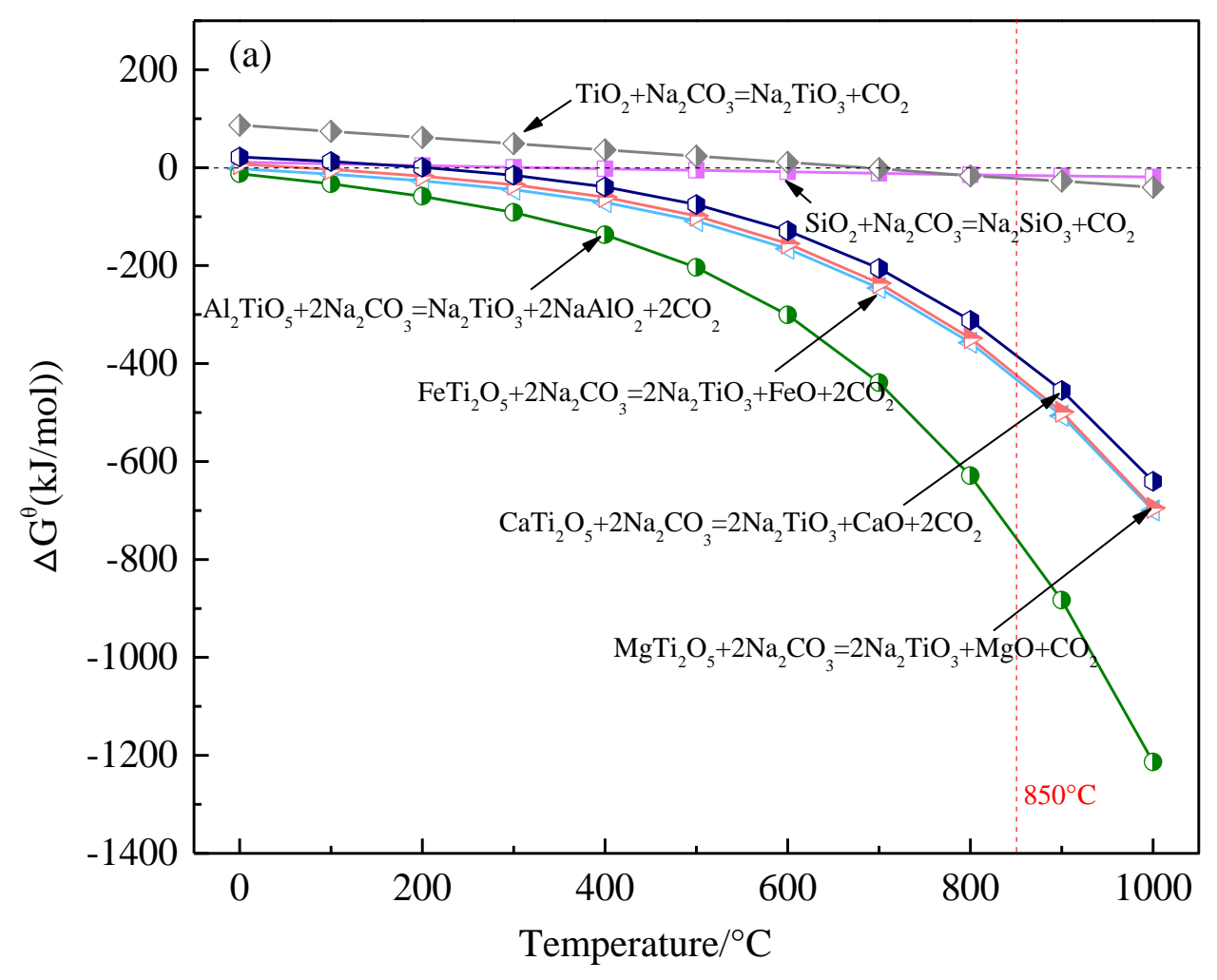




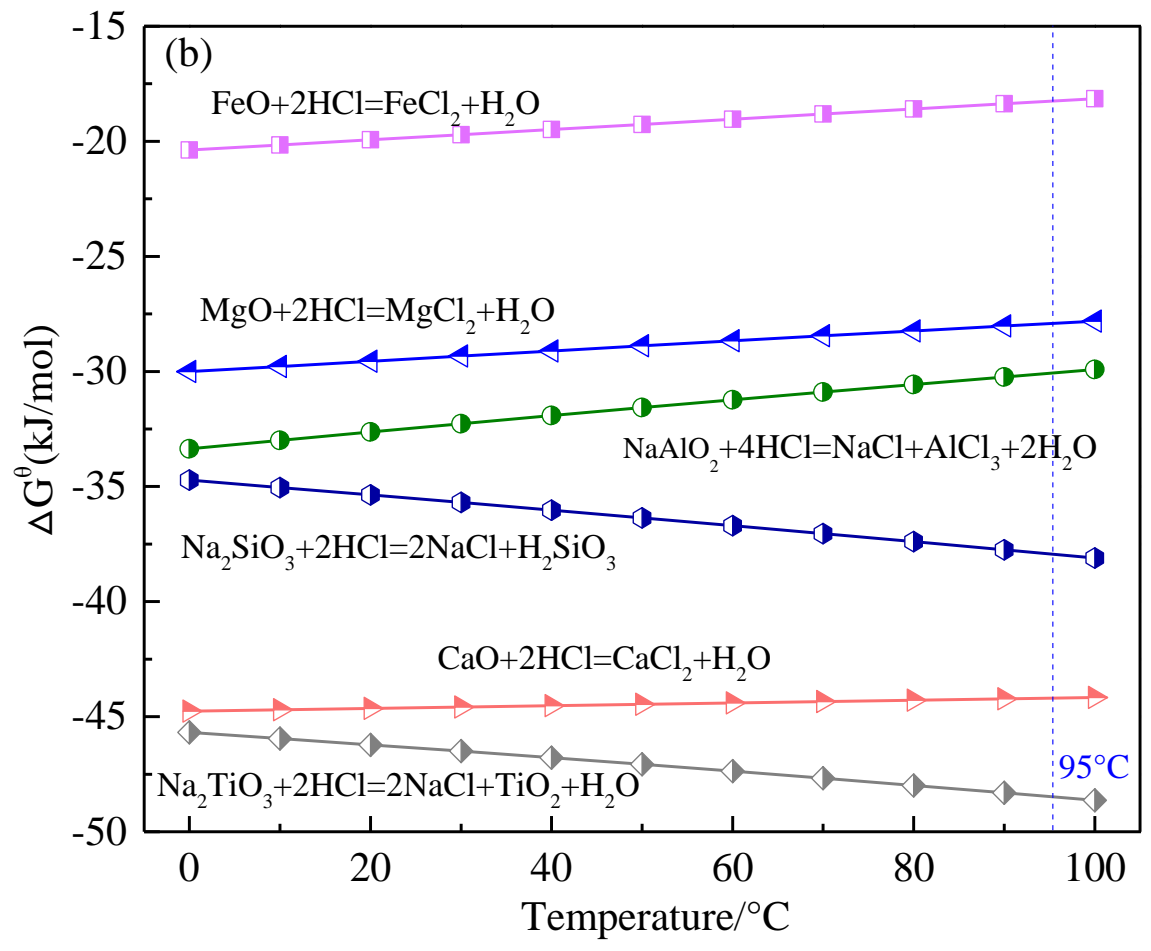


Figure 3

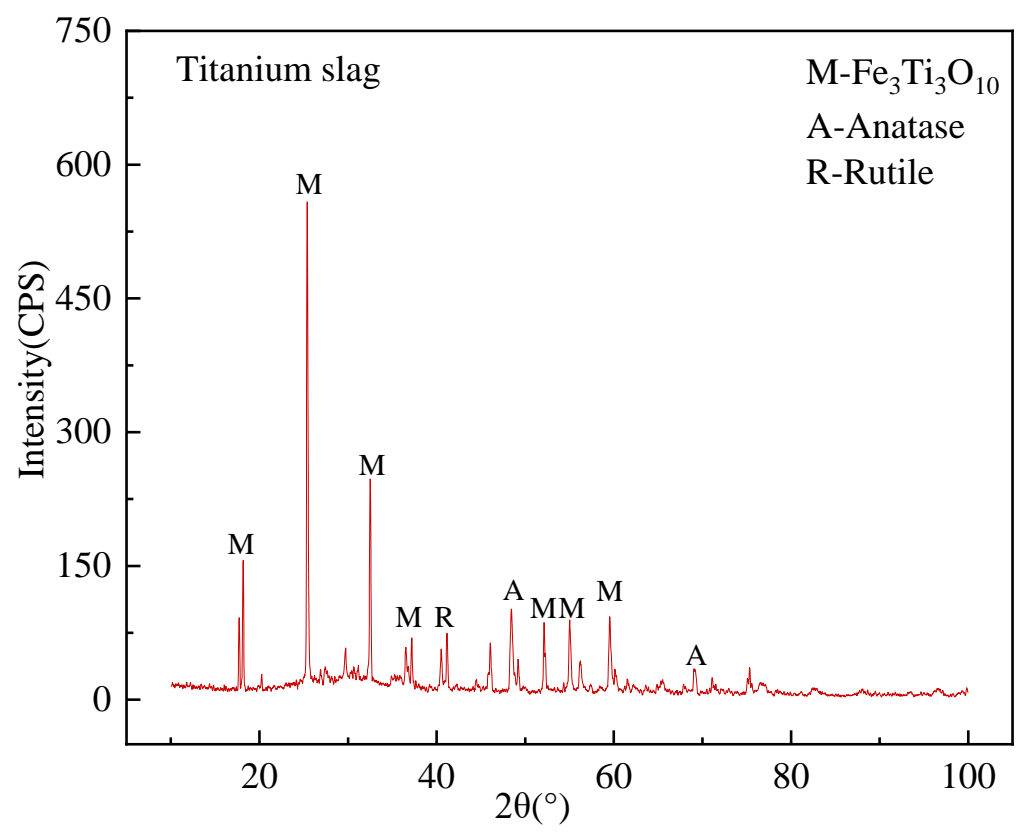




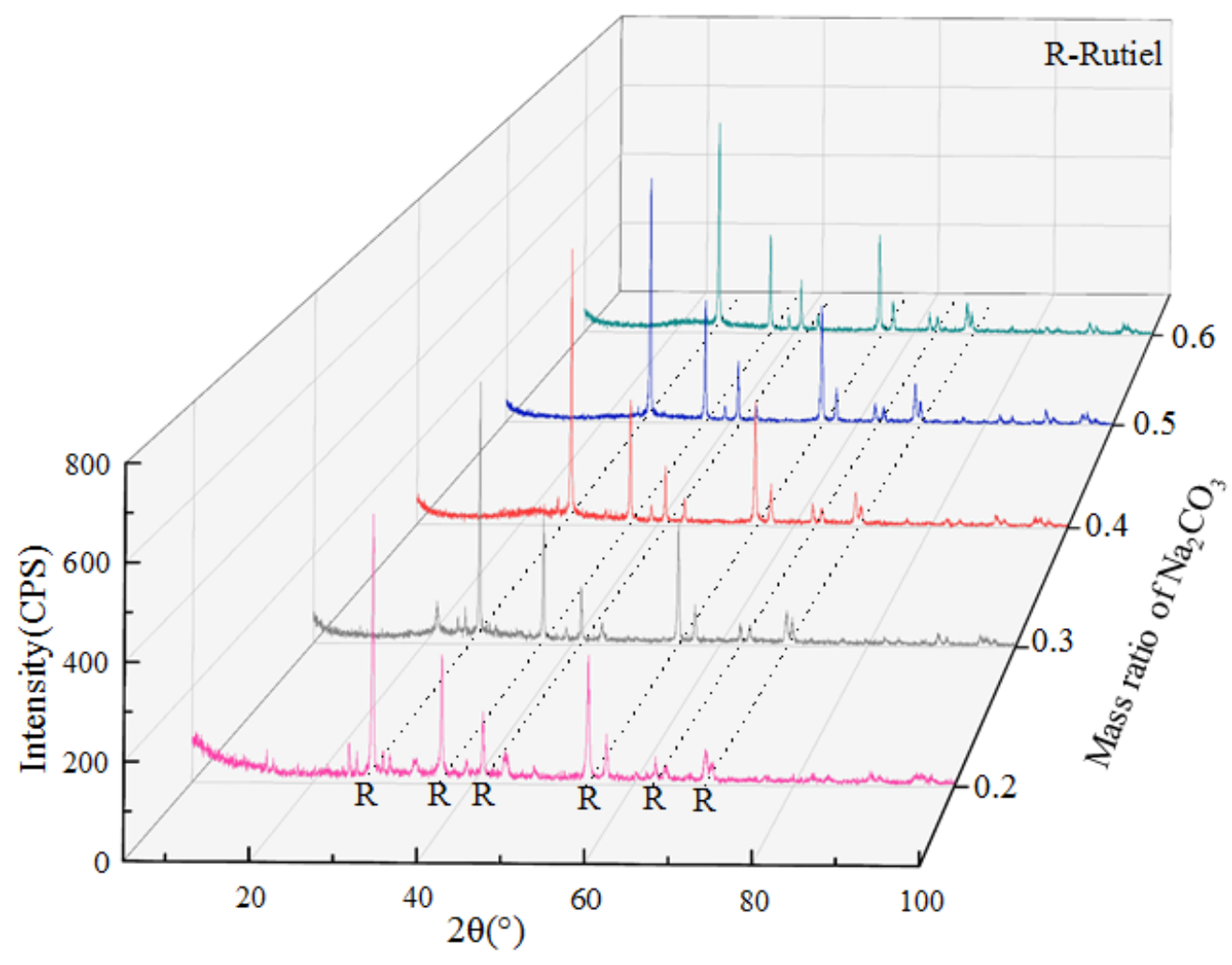




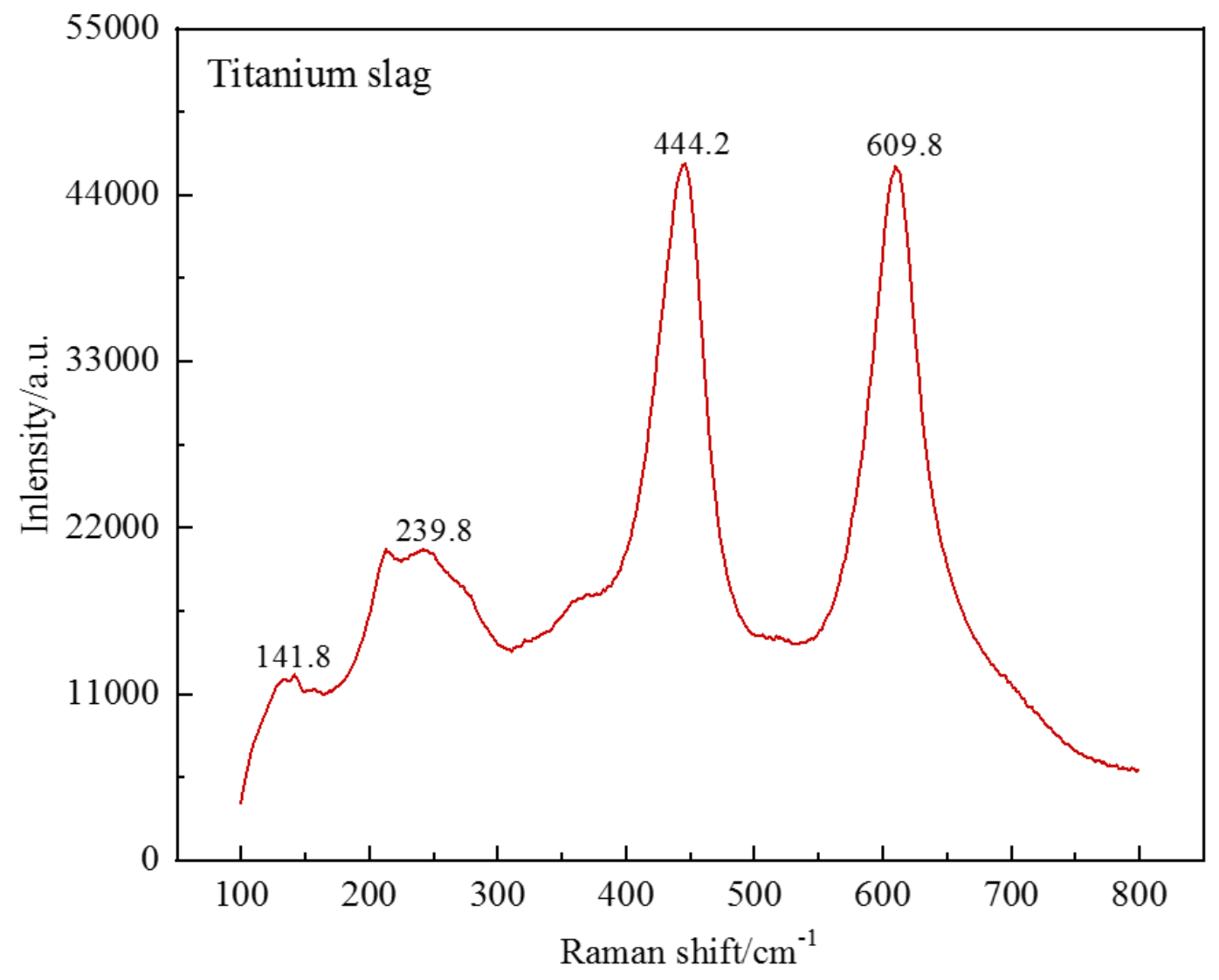




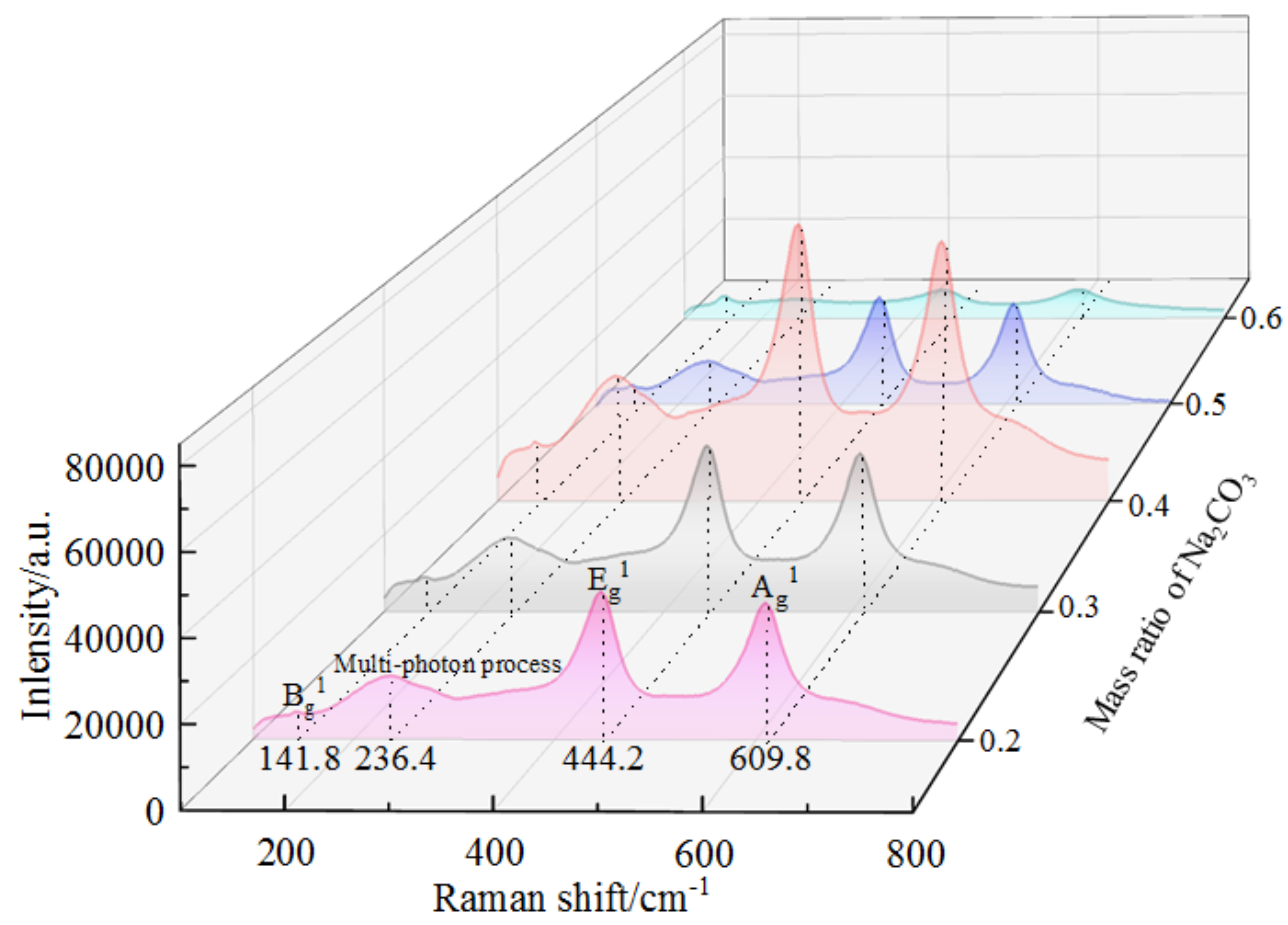




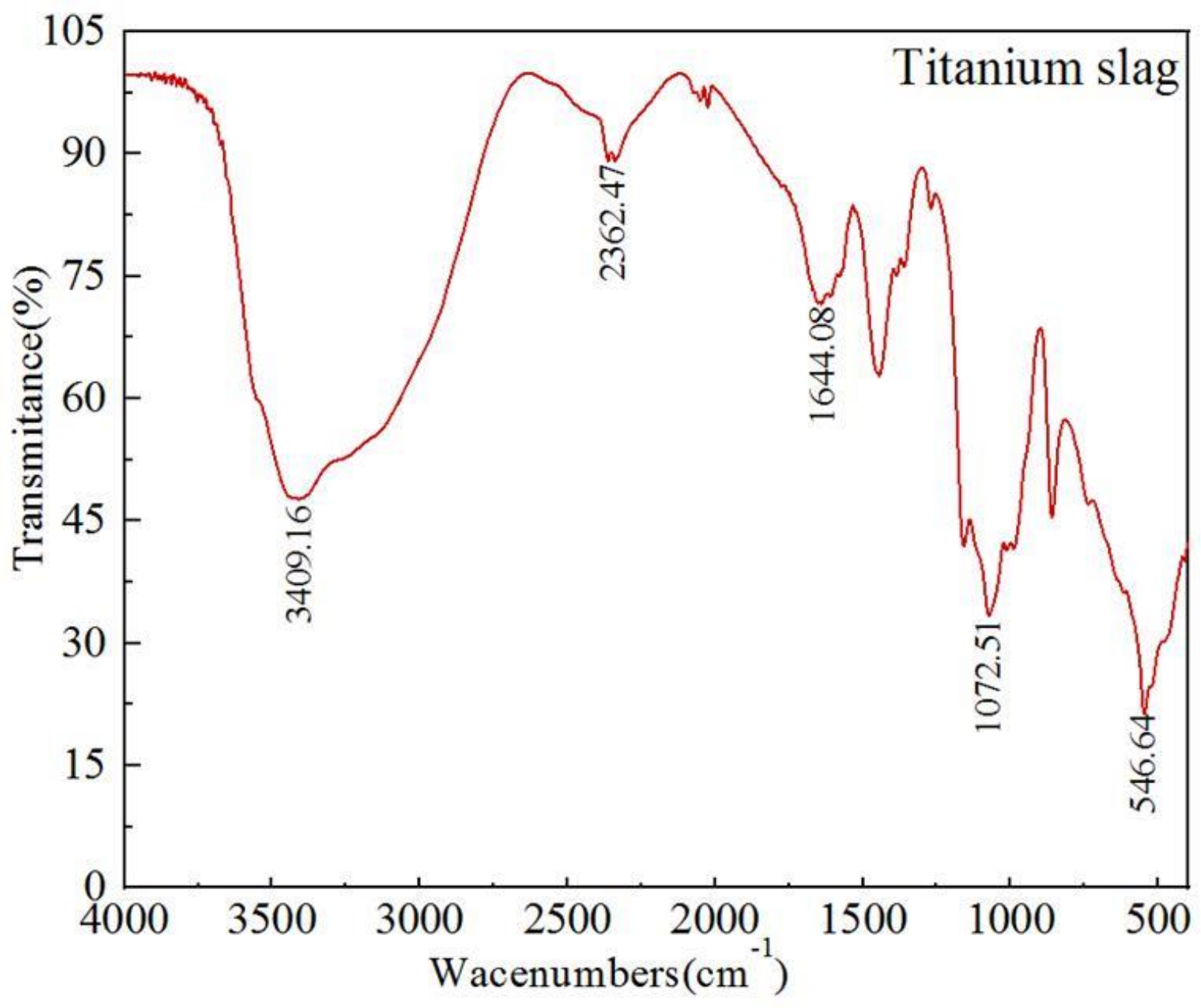




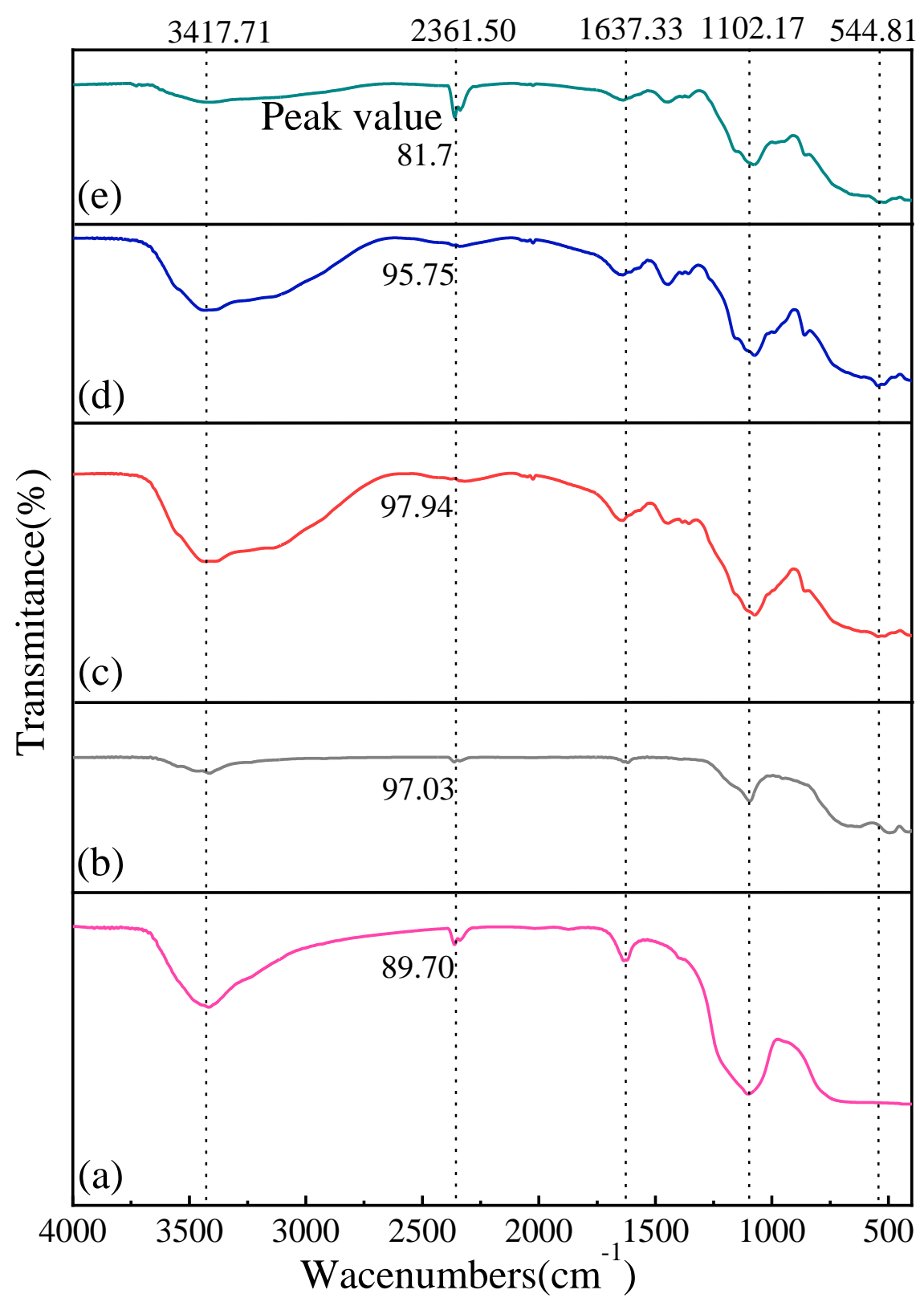



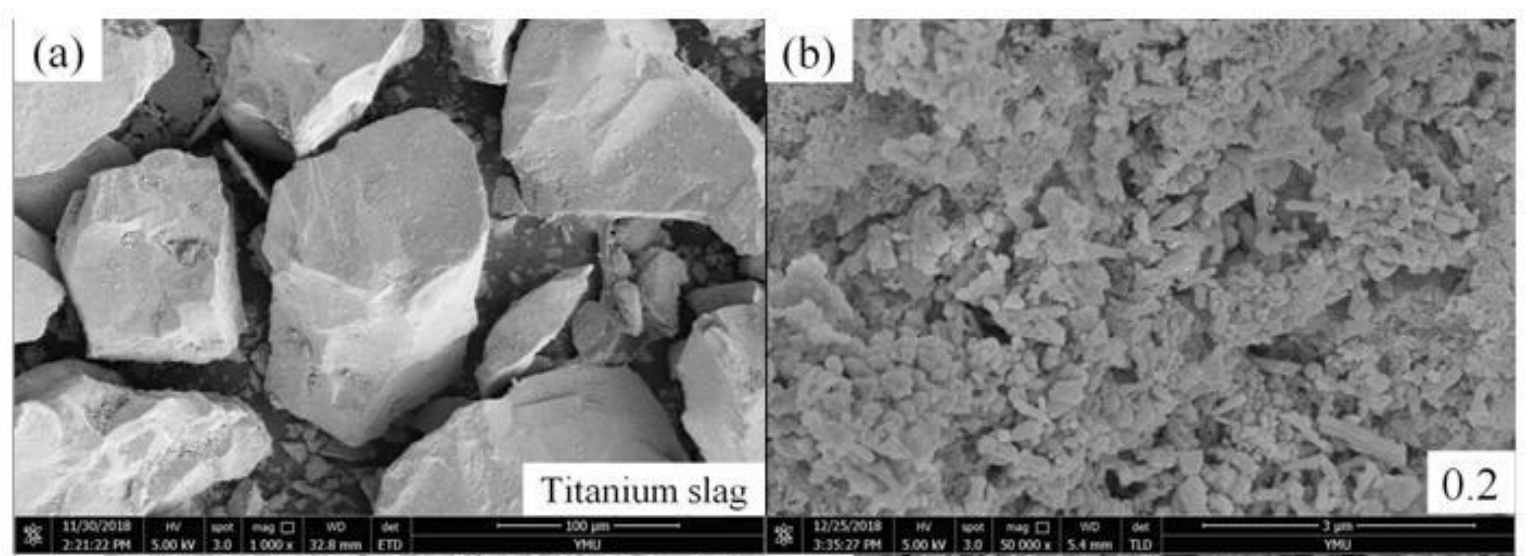

(c) 3.

(d)

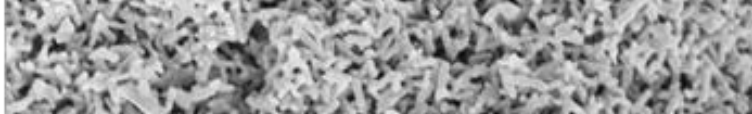

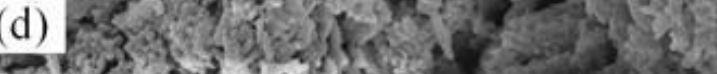

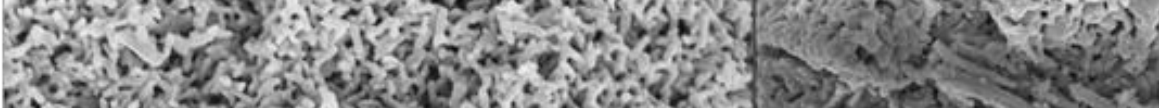

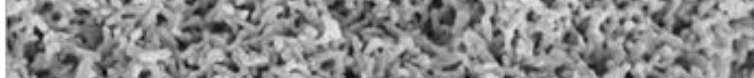

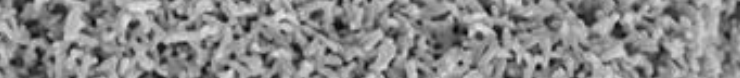

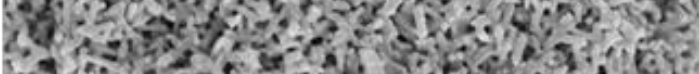

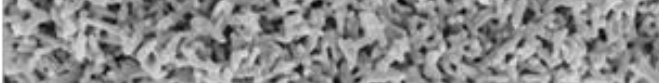

7. 3 .

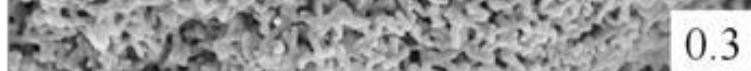

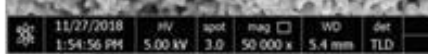

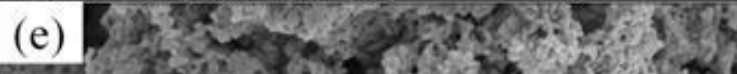

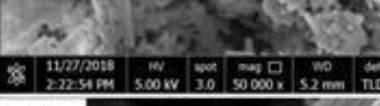

\section{(f)}

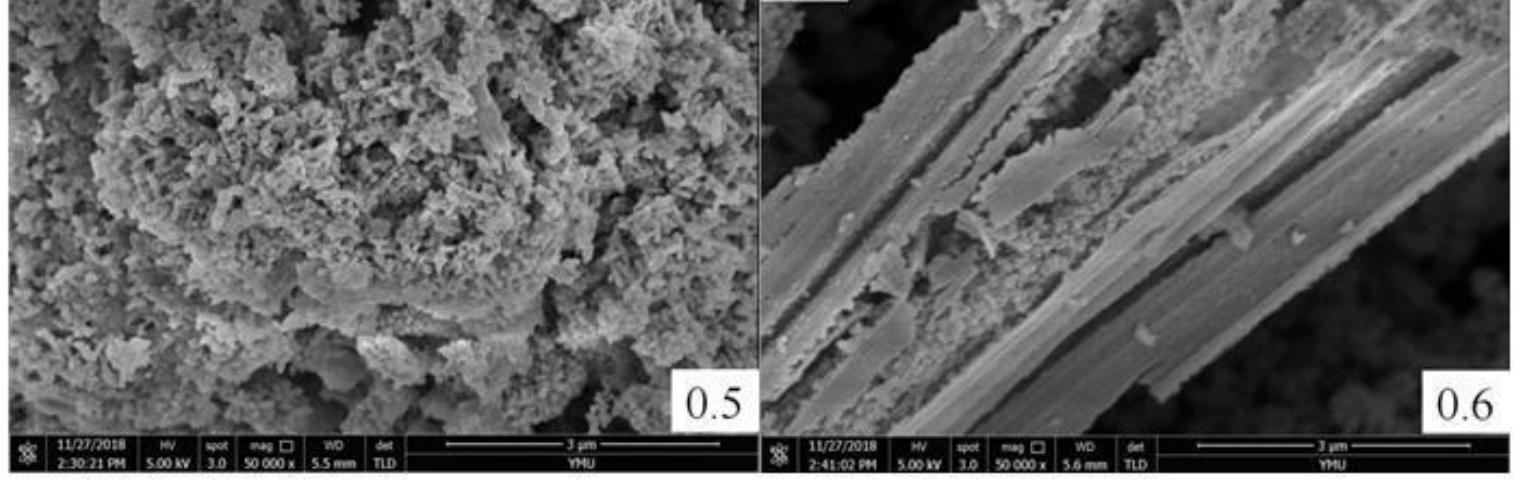


Table 1 Main chemical composition of the titanium slag (\%)

\begin{tabular}{cccccccccc}
\hline & $\mathrm{TiO}_{2}$ & $\mathrm{TFe}$ & $\mathrm{Al}_{2} \mathrm{O}_{3}$ & $\mathrm{SiO}_{2}$ & $\mathrm{MgO}$ & $\mathrm{CaO}$ & $\mathrm{S}$ & $\mathrm{P}$ & Others \\
\hline $\begin{array}{c}\text { Mass } \\
\text { fraction }\end{array}$ & 75.34 & 9.72 & 5.87 & 5.23 & 1.23 & 1.81 & 0.56 & 0.19 & 0.05 \\
\hline
\end{tabular}


Table 2 Structural parameters of the calcined products

\begin{tabular}{ccccc}
\hline \multirow{2}{*}{ Mass of $\mathrm{Na}_{2} \mathrm{CO}_{3}$} & \multicolumn{2}{c}{ Lattice parameters/A } & $\mathrm{D} / \mathrm{nm}$ & crystallinity \\
& $\mathrm{a}, \mathrm{b}$ & $\mathrm{c}$ & & \\
\hline 0.2 & 4.5954 & 2.9585 & 40.1 & $96.39 \%$ \\
0.3 & 4.59439 & 2.9576 & 58.0 & $92.53 \%$ \\
0.4 & 4.59306 & 2.95896 & 43.5 & $99.21 \%$ \\
0.5 & 4.58914 & 2.95738 & 44.7 & $98.23 \%$ \\
0.6 & 4.59406 & 2.95984 & 43.8 & $98.45 \%$ \\
\hline
\end{tabular}

